\section{Hepatic Messenger Ribonucleic Acid Activity Profiles in Experimental Azotemia in the Rat Relationship to Food Intake and Thyroid Function}

\author{
William B. Kinlaw, Harold L. Schwartz, Cary N. Mariash, \\ Christopher Bingham, Frances E. Carr, \\ and Jack H. Oppenheimer \\ Division of Endocrinology and Metabolism, Department of \\ Medicine, University of Minnesota, Minneapolis, Minnesota \\ 55455, and Department of Applied Statistics, University of \\ Minnesota, St. Paul, Minnesota 55108
}

bstract. We have studied the hepatic messenger RNA (mRNA) activity profile in chronically azotemic rats and sought to determine whether the observed changes could be mediated either by reduced food intake or diminished thyroid function at the tissue level. mRNA activity profiles were produced by twodimensional gel electrophoretic separation of radioactively labeled products of an in vitro reticulocyte lysate system which had been programmed by hepatic RNA. Of the $\sim 240$ translational products identified in this system, seven sequences were consistently altered in azotemia. In pair-fed animals six of these also decreased, but the alterations in three were depressed to a significantly lesser extent in the pair-fed group. Moreover, analysis of covariance suggested that food intake could account for the differences in only one sequence. The possibility that the mRNA activity profile in azotemia could represent the effects of diminished thyroid function was minimized by the finding that the reductions in plasma thyroxine $\left(T_{4}\right)$ and triiodothyronine $\left(T_{3}\right)$ levels observed were due largely to reduced plasma protein binding, with maintenance of the mean free $\mathrm{T}_{4}$ and free $T_{3}$ concentrations within the normal range. The changes in only one mRNA sequence could be related to free $T_{3}$ levels alone. Our findings, therefore, indicate that

All authors are associated with the Division of Endocrinology and Metabolism, Department of Medicine, except for Dr. Bingham, who is a member of the Department of Applied Statistics.

Address reprint requests to Dr. Oppenheimer, Box 91, Mayo Memorial Building, University of Minnesota, Minneapolis, MN 55455.

Received for publication 9 February 1984 and in revised form 16 August 1984.

J. Clin. Invest.

(c) The American Society for Clinical Investigation, Inc. 0021-9738/84/12/1934/08 $\$ 1.00$

Volume 74, December 1984, 1934-1941 although diminished food intake and reduced thyroid function may contribute to some of the observed changes in the mRNA activity profiles, the bulk of alterations in azotemia appear to be mediated by other mechanisms. The striking overlap between the sequences affected by azotemia and pair-feeding raises the speculation that altered gene expression in azotemia may reflect an impaired hepatic response at the pretranslational level to metabolic signals associated with food intake.

\section{Introduction}

Despite a voluminous literature dealing with hormonal and nutritional factors in systemic disease, the precise mechanism leading to the catabolic diathesis associated with such disorders remains unclear. It occurred to us that important information about these processes at the genomic level could be obtained by examining the hepatic messenger RNA (mRNA) activity profile. This technique involves the resolution by two-dimensional gel electrophoresis of radioactively labeled products translated in an in vitro system programmed by RNA from the tissues of experimentally manipulated animals. Previous studies in our laboratory had shown a high degree of specificity in the hepatic mRNA activity profiles in hypothyroidism, hyperthyroidism, high carbohydrate feeding, starvation, and experimental diabetes (1-3). Thus, it appeared possible that distinctive mRNA patterns might also characterize various experimental models of systemic disease.

To test this possibility, we chose to study chronic azotemia produced by subtotal nephrectomy in the rat. This model was of special interest to us since the decreased food intake and growth retardation that accompany it reflect similar phenomena in the clinical uremic syndrome (4). Moreover, a recent report by Lim et al. (5) indicates that the level of circulating triiodothyronine $\left(T_{3}\right)^{1}$ is reduced in the chronically partially ne-

1. Abbreviations used in this paper: $\alpha$-GPD, alpha-glycerolphosphate dehydrogenase; MCR, metabolic clearance rate; ME, malic enzyme; $\mathrm{N} / \mathrm{P}$, nuclear/plasma; $T_{3}$, triiodothyronine; $T_{4}$, thyroxine. 
phrectomized rat, as has been observed in azotemic man (6). This report also suggested that in the rat model the reduction in circulating $T_{3}$ leads to tissue hypothyroidism, as reflected by reduced activities of hepatic alpha-glycerolphosphate dehydrogenase ( $\alpha$-GPD) and malic enzyme (ME). We therefore set out to define the mRNA profile in azotemia. Furthermore, we addressed ourselves to the specific question of whether or not the changes in the mRNA activity profile produced in azotemia could be explained either by a reduction in food intake or by the development of tissue hypothyroidism.

\section{Methods}

Azotemia was established by two-stage subtotal nephrectomy in male Sprague-Dawley rats $(250 \mathrm{~g}$ body $w t)$ by the method of Chanutin and Ferris (7). The second stage of nephrectomy was performed $4 \mathrm{~d}$ after the first stage. All animals were housed singly throughout the experiment. Nephrectomized and control rats had access to Purina Rat Chow (Ralston Purina Co., St. Louis, MO) ad lib. Each rat of the third group, pair-fed controls, received a ration equal to that consumed by its azotemic mate the previous day. Animals were killed $21 \mathrm{~d}$ after the first stage of nephrectomy. Liver was frozen immediately at $-80^{\circ} \mathrm{C}$ and plasma was removed and frozen at $-20^{\circ} \mathrm{C}$ for further determinations.

mRNA activity profiles were determined by a modification of the technique previously described (1). Total hepatic RNA was extracted in $8 \mathrm{M}$ guanidine hydrochloride (8). $20 \mu \mathrm{g}$ of total RNA was added in vitro to a rabbit reticulocyte lysate system (Bethesda Research Laboratories, Bethesda, MD) in the presence of ${ }^{35}$ S $]$ methionine (Amersham Corp., Arlington Heights, IL). The protocol recommended by the supplier was followed with the exception that additional magnesium chloride was not added to the reaction mixture. Two-dimensional gel electrophoresis of the translated products $\left(1 \times 10^{6}\right.$ trichloroacetic acidprecipitable cpm per gel) was performed as originally described by O'Farrell (9). Autoradiograms of the two-dimensional gels were prepared and each spot was assigned an arbitrary reference number (see Fig. 1) by the nomenclature of Seelig et al. (1). As detailed in Carr et al. (3), gels were visually inspected to determine those spots that showed consistent changes from one state to another on all gels. Such spots were quantitated by computer-assisted videodensitometry (10). To validate this procedure, Carr et al. (3) quantitated a group of spots chosen by number from a random number table. None of these was found to be significantly altered. In the present study, $\sim 30$ spots thought not to be altered after visual inspection were quantitated. No significant treatment-related differences in mean values were observed. Since equal amounts of radioactivity were applied to each gel, intensities of individual autoradiographic spots represent the relative translational activity of the corresponding hepatic mRNA sequence.

Activities of hepatic ME (11) and mitochondrial $\alpha$-GPD (12), as well as total protein (13), DNA (14), and RNA (15) were measured as previously described. Plasma thyroxine $\left(T_{4}\right)$ was measured by radioimmunoassay with a commercially available kit (Kallestad Laboratories, Inc., Austin, TX), and plasma $T_{3}$ concentrations were measured by the method of Surks et al. (16). Serum blood urea nitrogen and creatinine were determined by the clinical laboratory at the University of Minnesota Hospitals using an automated method (Autoanalyzer). The plasma dialysis fraction of $T_{4}$ and $T_{3}$ were determined as previously described (17) at dilutions of $1: 150$ and $1: 15$, respectively.

Metabolic clearance rates (MCRs) of $T_{3}$ and $T_{4}$ were determined by standard isotopic techniques (18). Trichloroacetic acid-precipitable radioactivity in plasma was measured at $5 \mathrm{~min}$ and at $3,6,12,18$, and $24 \mathrm{~h}$ after intravenous injection of tracer quantities $(<5.0 \mathrm{ng})$ of $\left[{ }^{125} \mathrm{I}\right] \mathrm{T}_{3}$ or $\left[{ }^{125} \mathrm{I}\right] \mathrm{T}_{4}$ (Abbott Laboratories, North Chicago, IL). The disappearance curves were analyzed by the noncompartmental method (19). Production rates were calculated from the product of the MCR and the concentration of circulating hormone measured by radioimmunoassay.

In order to estimate the $T_{3}$ content of hepatic nuclear $T_{3}$ receptors in vivo, four animals from each experimental group were injected intravenously with tracer quantities of $\left[{ }^{125} \mathrm{I}\right] \mathrm{T}_{3}$ with or without an accompanying loading dose of nonradioactive $\mathrm{T}_{3}(10 \mu \mathrm{g} / 100 \mathrm{~g}$ body wt). Animals were killed 30 min later. The nuclear/plasma ratio was determined as previously described with appropriate subtraction of the nonspecific nuclear/plasma (N/P) ratio (20). The nuclear content of $T_{3}$ was estimated from the product of the specific $N / P$ ratio and the concentration of plasma $T_{3}$.

Statistical evaluation of differences between groups was performed by a one-way analysis of variance using the Newman-Kuels procedure (21). The analysis of covariance (21), using hepatic nuclear $T_{3}$ content, plasma free $T_{3}$ concentration, food intake, or combinations of these variables as covariates, was applied to the logarithmically transformed spot intensities $\left[\log _{n}\right.$ (spot intensity +1$\left.)\right]$ to assess the possibility that these variables could be determinants of spot intensity. The significance of differences between mean group spot intensities after adjustment by analysis of covariance was assigned by the two-tailed $t$ test (21).

\section{Results}

The effects of experimental conditions on food intake and growth are displayed in Fig. 2. After the second-stage nephrectomy, the azotemic rats ate only $52 \%$ of the amount of food consumed by the normal control rats. Weight gain ceased. Likewise, equivalent restriction of food intake of unoperated animals also led to a cessation of weight gain. In Table I are summarized data from a separate series of studies in which the effects of azotemia on hepatic composition were examined. In this series, by day 21 there was not only cessation of growth but some loss of body weight. The azotemic and pair-fed control animals weighed 89 and $86 \%$ of their initial body weights, respectively, whereas control animals fed ad lib. averaged $129 \%$ of their starting value. $60 \%$ of the operated animals died within $48 \mathrm{~h}$ of the second stage of nephrectomy, but there were no deaths among the pair-fed control group.

At $21 \mathrm{~d}$ the liver weight of the azotemic and pair-fed animals was also significantly lower than that of controls fed ad lib. (Table I), presumably as a result of growth arrest. There were no significant differences in the hepatic RNA/DNA ratio or the protein/DNA ratio among the groups. The normal hepatic RNA and protein content of the azotemic and pairfed control rats contrasts with the markedly reduced RNA and protein content of livers of totally starved rats (2).

Plasma $\mathrm{T}_{3}$ levels were significantly $(P<0.05)$ depressed in the azotemic animals to $69 \%$ of the control values, but were unchanged in pair-fed rats (Table II). The plasma $T_{4}$ concentration in the azotemic and pair-fed animals fell significantly $(P<0.05)$ to 47 and $77 \%$ of the comparable values in the ad lib. fed controls, respectively. However, decreased plasma 


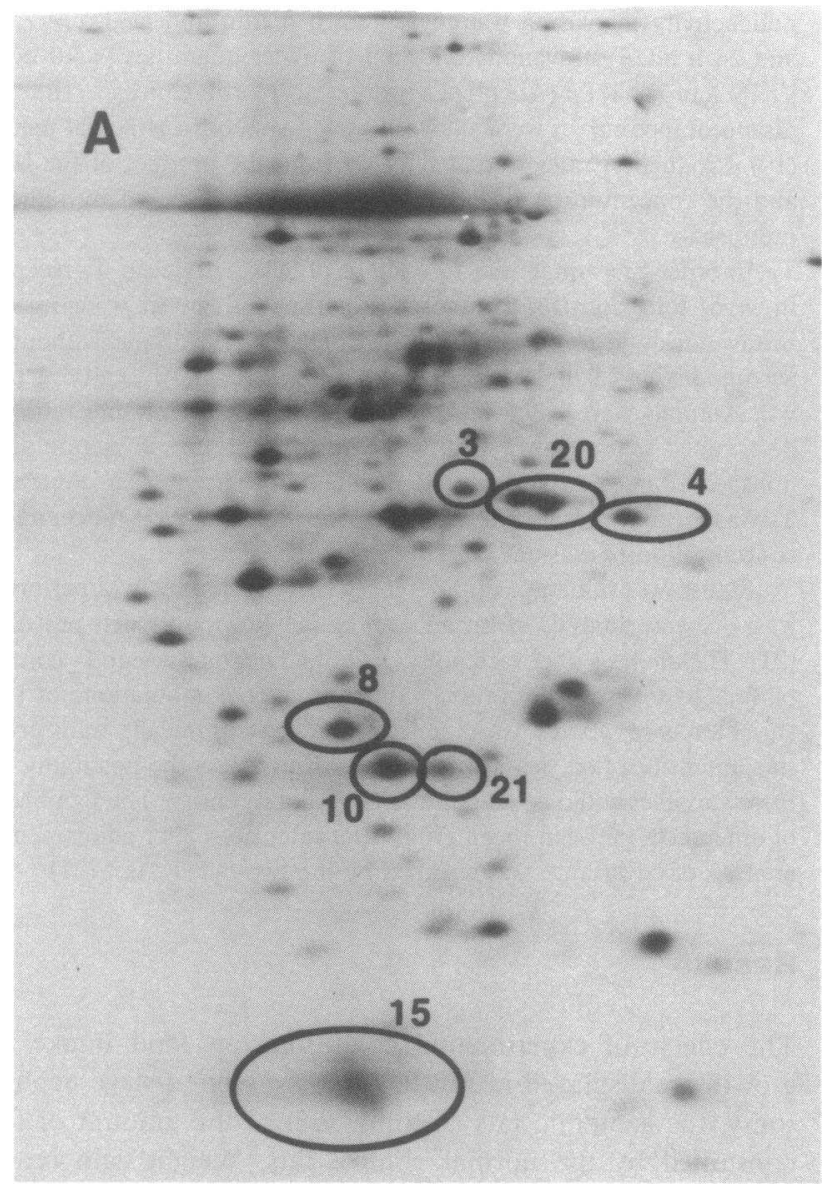

Figure 1. Representative autoradiographs prepared from two-dimensional gel electrophoretograms of the in vitro translation products of hepatic mRNA extracted from an individual ad lib.-feeding control rat $(A)$ and a chronically azotemic rat $(B)$. Separation of proteins is by decreasing molecular weight (top to bottom) and by isoelectric point (acidic left, basic right). Circled spots were determined by visual inspection of all gels to be consistently altered by experimental manipulation. Videodensitometric analysis showed these to be signifi-

binding in the azotemic animals was apparent from the increased dialysis fractions both for $T_{3}$ and $T_{4}$. Thus, in both azotemic and pair-fed control groups, the mean free thyroid hormone concentrations were not statistically different from those of the ad lib.-fed control animals.

The subgroup of azotemic animals used in turnover studies (Table III) demonstrated a similar reduction in circulating $T_{4}$ and $T_{3}$ concentrations, to 57 and $66 \%$ of control levels, respectively. There was an increase in the MCR of each hormone, which was sufficient to yield a daily production rate for $T_{3}$ and $T_{4}$ not different from control values. The increase in MCR is the expected consequence of the diminished plasma protein binding of both $T_{3}$ and $T_{4}$.

It appeared possible, however, that hypothyroidism could

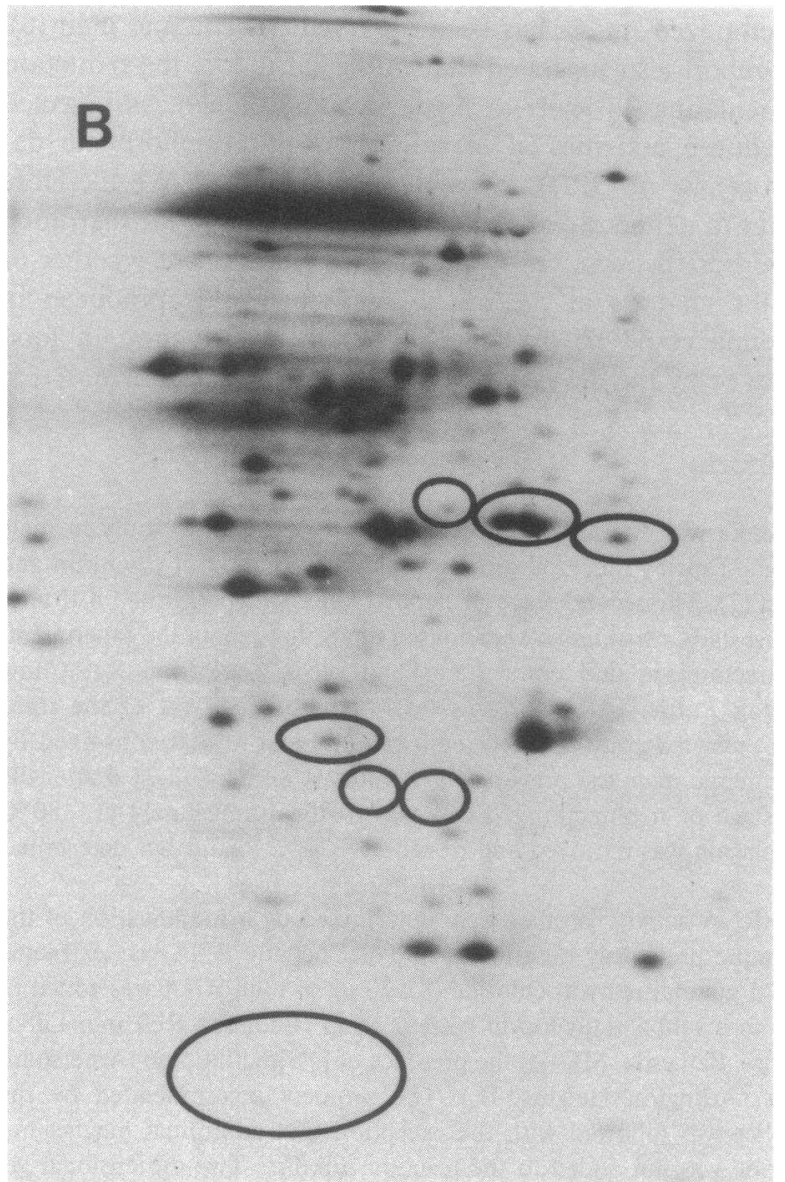

cantly altered $(P<0.05)$ in azotemic and pair-fed groups. Although other spots were observed to increase or decrease on individual gels, they did not display consistent treatment-related changes. Nomenclature is that of Seelig et al. (1) and is the same as that used in Table IV. Pair-fed rats demonstrated alterations smaller than those observed in azotemia for most spots. The individual azotemic rat represented did not demonstrate a reduction in the activity of spot 20.

result from diminished nuclear $T_{3}$ binding. Therefore, we estimated the total nuclear $T_{3}$ content from the product of the plasma $T_{3}$ and the isotopically determined hepatic nuclear/ plasma ratios in separate groups of four azotemic, pair-fed, and ad lib.-fed controls. No differences were found between ad lib.-fed and azotemic animals (Table II). It is curious that the N/P $T_{3}$ ratio in the food-restricted animals rose and yielded a small but significant increase in the calculated nuclear $T_{3}$ content. The levels of hepatic $\alpha$-GPD activity in azotemic, pair-fed, and control groups were indistinguishable from each other. No difference was found between the levels of ME activity in azotemic and ad lib.-fed controls. Unexpectedly, the pair-fed group showed a slight increase in ME activity. The normal activities of these highly $T_{3}$-responsive enzymes 

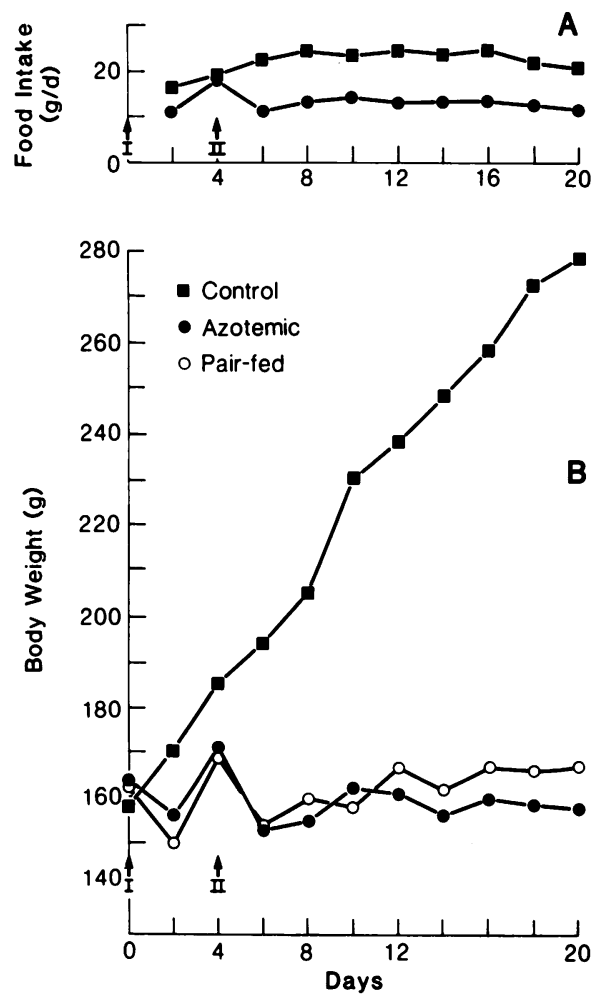

Figure 2. Food intake and weight gain in azotemic and pair-fed rats. $(A)$ Mean daily food intake in azotemic ( $\bullet$ ) and ad lib.-fed control ( () rats. Food consumption by pair-fed controls was identical to that of the azotemic group. Data are from an experiment that included four rats in each group. I indicates the time of $2 / 3$ left nephrectomy, and II shows the time of right nephrectomy in the azotemic group. (B) Mean body weight of azotemic (๑), pair-fed (0), and ad lib.-fed ( () rats.

therefore are consistent with a euthyroidal state of hepatic tissues in our azotemic preparation.

The hepatic mRNA activity profiles, however, revealed striking and consistent changes in the pair-fed and azotemic animals (Table IV). Of the $\sim 240$ individual mRNA translational products apparent on the gels, attention was focused on 30 that appeared possibly to change upon visual assessment of the autoradiographs. Videodensitometric quantitation of these showed that the activities of seven fell significantly in the azotemic as compared with the normal ad lib.-fed animals (spots 3, 4, 8, 10, 15, 20, and 21) (Table IV). No products were increased as a result of azotemia. The changes in pairfed animals bore a striking resemblance to those noted in azotemia, with a reduction in six of the seven spots observed to decrease in azotemia; only spot 4 failed to change significantly in the pair-fed group. No unique changes were seen in pairfed rats. No significant alterations of any spots were observed in a group of sham-operated controls (data not shown).

Of the six spots altered in both azotemic and pair-fed rats,
Table I. Effects of Azotemia on Growth and Liver Composition

\begin{tabular}{lccc}
\hline & $\begin{array}{l}\text { Control } \\
(9)\end{array}$ & $\begin{array}{l}\text { Pair fed } \\
(18)\end{array}$ & $\begin{array}{l}\text { Azotemic } \\
(19)\end{array}$ \\
\hline BUN $(m g / d l)$ & $19 \pm 2.0^{*}$ & $13 \pm 0.5$ & $85 \pm 9 \neq \S$ \\
Creatinine $(m g / d l)$ & $0.7 \pm 0.03$ & $0.5 \pm 0.02$ & $2.0 \pm 0.3 \pm \S$ \\
Final animal weight & & & \\
$\quad$ (\% of initial) & $129 \pm 3$ & $86 \pm 3 \ddagger$ & $89 \pm 4 \ddagger$ \\
Liver weight $(g)$ & $11.4 \pm 0.2$ & $6.1 \pm 0.4 \ddagger$ & $7.3 \pm 0.3 \ddagger$ \\
DNA (mg/g liver) & $2.8 \pm 0.2$ & $3.4 \pm 0.2$ & $3.3 \pm 0.1$ \\
RNA/DNA $(m g / m g)$ & $3.3 \pm 0.2$ & $2.6 \pm 0.2$ & $3.0 \pm 0.1$ \\
Protein $(m g / m g ~ D N A)$ & $57 \pm 4$ & $49 \pm 3$ & $47 \pm 2$ \\
& & & \\
\hline
\end{tabular}

Azotemia and pair feeding were of $21 \mathrm{~d}$ duration. Numbers in parentheses indicate number of animals studied. BUN, blood urea nitrogen.

* Mean \pm SEM. Rats were 8 wk old at the start of the experiment, and of comparable initial weight $(253 \pm 4 \mathrm{~g})$.

$\ddagger$ Different from control, $P<0.05$.

$\S$ Different from pair fed, $P<0.05$.

there was a significantly greater diminution in the azotemic group for spots 10,15 , and 21. For example, spot 15 was depressed to $3 \%$ of the control value in azotemic rats, in contrast to the pair fed group, which exhibited only a 54\% reduction. These differences indicated that reduced food intake could not completely explain the changes in the azotemic group.

Although the mean free $T_{3}$ concentrations in control and azotemic animals did not differ significantly, $\sim 20 \%$ of the free $\mathrm{T}_{3}$ values in the azotemic group were $\geq 2$ SD below the mean of the ad lib.-fed controls. We therefore examined the possibility that the free $T_{3}$ concentration could be the only determinant of the intensity of individual spots by applying analysis of covariance (21). In addition, we used this statistical approach to assess the potential contributions of nuclear $T_{3}$ and food intake. The results demonstrated that although a significant relationship between spot intensity and the nuclear $T_{3}$ or free $T_{3}$ concentration was present, significant differences remained among the groups for all spots except spot 3. Similarly, adjustment for food intake did not correct for group differences except for spot 8 (Table V). Analysis of the mean spot intensities in relationship to the combined variables of nuclear $T_{3}$ content and food intake showed that significant differences persisted among the groups for most of the spots.

\section{Discussion}

Our results clearly show that rats rendered azotemic by subtotal nephrectomy demonstrate an abrupt cessation in the growth of the total body and liver. Similarly, the unchanged hepatic DNA concentration as compared with that of controls suggests a cessation of hepatocellular replication. These changes presumably reflect the catabolic manifestations that are usually associated with the azotemic syndrome. Of interest was the 
Table II. Thyroid Hormones and $T_{3}$ Responsive Hepatic Enzymes in Azotemia

\begin{tabular}{|c|c|c|c|}
\hline & Control & Pair fed & Azotemic \\
\hline $\mathrm{T}_{3}(n g / m l)$ & $0.80 \pm 0.06^{*}(9)$ & $0.72 \pm 0.04(18)$ & $0.55 \pm 0.05 \quad(17) \ddagger \S$ \\
\hline $\mathrm{DF}_{3} \times 10^{2}$ & $9.5 \pm 0.2$ & $8.7 \pm 0.2$ & $11.6 \pm 0.41 \neq \S$ \\
\hline $\mathrm{FT}_{3} \times 10^{4}(\mathrm{ng} / \mathrm{ml})$ & $6.7 \pm 0.3$ & $5.2 \pm 0.2$ & $5.6 \pm 0.6$ \\
\hline $\mathrm{T}_{4}(n g / m l)$ & $57 \pm 6$ & $44 \pm 3 \ddagger$ & $27 \pm 3 \ddagger \S$ \\
\hline $\mathrm{DF}_{4} \times 10^{2}$ & $6.5 \pm 0.3$ & $6.0 \pm 0.04 \quad(6)$ & $9.7 \pm 0.4 \quad(7) \ddagger \S$ \\
\hline $\mathrm{FT}_{4}(\mathrm{ng} / \mathrm{ml})$ & $2.00 \pm 0.17$ & $1.73 \pm 0.12 \quad(6)$ & $1.86 \pm 0.04$ \\
\hline$\alpha$-GPD $(O D /$ min per mg protein $)$ & $0.068 \pm 0.006(11)$ & $0.070 \pm 0.03$ & $0.068 \pm 0.005(16)$ \\
\hline Malic enzyme (U/mg protein) & $8.5 \pm 0.8 \quad(12)$ & $14.3 \pm 1.4 \quad(14) \ddagger$ & $8.5 \pm 0.8 \quad(16) \S$ \\
\hline$\left[{ }^{125} \mathrm{I}\right] \mathrm{T}_{3}(\mathrm{~N} / \mathrm{P})$ & $0.461 \pm 0.020(4)$ & $0.643 \pm 0.054(4) \ddagger$ & $0.575 \pm 0.036(4) \S$ \\
\hline Nuclear $\mathrm{T}_{3}(n g / m g D N A)$ & $0.37 \pm 0.03$ & $0.46 \pm 0.03 \quad(18) \ddagger$ & $0.32 \pm 0.03(19) \S$ \\
\hline
\end{tabular}

* Numbers in parentheses indicate number of animals studied. All data presented as mean $\pm \mathrm{SEM} . \mathrm{DF}_{3}$ and $\mathrm{DF}_{4}$ indicate dialysis fractions for $\mathrm{T}_{3}$ and $\mathrm{T}_{4}$ at plasma dilutions of $1: 15$ and $1: 150$, respectively. $\left[{ }^{125} \mathrm{I}\right] \mathrm{T}_{3}(\mathrm{~N} / \mathrm{P})$ indicates the ratio of $\left[{ }^{125} \mathrm{I}\right] \mathrm{T}_{3}$ specifically bound to hepatic nuclei to the $\left[{ }^{125} \mathrm{ITT}_{3}\right.$ in plasma 30 min after tracer ${ }^{125} \mathrm{I}_{\mathrm{T}} \mathrm{T}_{3}$ injection. Nuclear $\mathrm{T}_{3}$ was estimated by multiplying this ratio by plasma $\mathrm{T}_{3} . \mathrm{FT}_{3}$ and $\mathrm{FT}_{4}$, free $\mathrm{T}_{3}$ and $\mathrm{T}_{4}$, respectively. $\ddagger$ Different from control, $P<0.05$. § Different from pair fed, $P<0.05$.

finding that animals pair fed with the azotemic group showed precisely the same cessation in weight gain as that manifested by the azotemic animals, and demonstrated a comparable arrest in liver growth. These results are thus compatible with the hypothesis that growth retardation in the azotemic animals is mediated by a reduction in food intake. However, since it is possible that the diminution in food intake is secondary to a primary failure in the appropriate utilization of nutrients, a causal relationship between diminished food intake and growth retardation has not been established.

We have also examined the effect of azotemia on hepatic genomic expression as determined by mRNA activity profiles. Each spot visualized in such patterns is presumed to represent the translational activity of one mRNA sequence. Since there

Table III. Thyroid Hormone Kinetics in Azotemic Rats

\begin{tabular}{|c|c|c|c|}
\hline & Control & Pair fed & Azotemic \\
\hline $\begin{array}{r}\text { Plasma } T_{3} \\
(n g / m l)\end{array}$ & $0.72 \pm 0.06^{*}(5)$ & $0.61 \pm 0.02(6)$ & $0.48 \pm 0.03(6) \ddagger$ \\
\hline $\begin{array}{l}\text { MCR T } \mathrm{T}_{3}(\mathrm{ml} / 100 \mathrm{~g} \\
\text { bw per } h)\end{array}$ & $16.2 \pm 3.2$ & $17.2 \pm 1.2$ & $23.6 \pm 2.2$ \\
\hline $\begin{array}{c}\mathrm{PR} \mathrm{T}_{3}(n g / 100 \mathrm{~g} \\
b w \text { per } d)\end{array}$ & $289 \pm 66$ & $254 \pm 21$ & $302 \pm 48$ \\
\hline $\begin{array}{c}\text { Plasma } \mathrm{T}_{4} \\
(\mathrm{ng} / \mathrm{ml})\end{array}$ & $50 \pm 5$ & $44 \pm 3$ & $28 \pm 4 \quad(7)$ \\
\hline $\begin{array}{l}\operatorname{MCR~T}_{4}(\mathrm{ml} / 100 \mathrm{~g} \\
\operatorname{per} h)\end{array}$ & $1.34 \pm 0.09$ & $1.23 \pm 0.09$ & $2.20 \pm 0.49 \ddagger$ \\
\hline $\begin{array}{c}\mathrm{PR}_{\mathrm{T}}(n g / 100 \mathrm{~g} \\
\text { bw per d) }\end{array}$ & $1600 \pm 215$ & $1300 \pm 163$ & $1420 \pm 355$ \\
\hline
\end{tabular}

bw, body weight; PR, production rate.

* Mean \pm SEM. Numbers in parentheses indicate number of animals studied.

¥Different from control and pair fed, $P<0.05$. are $\sim 10,000$ expressed genes in the hepatic cell (22) and only $\sim 240$ spots are seen, it appears probable that the sequences represented in the autoradiographs are the translational products of mRNA's with multiple copies per cell. Though in many instances translational activity has been shown to be proportional to the mass of a specific mRNA this cannot be presumed to be the case for each of the sequences studied.

Our results showed that azotemia is associated with a statistically significant decrease in the activity of seven mRNA sequences. Of these, the identity of only one, that of spot 15 , has been established. Seelig (personal communication) has recently shown that this spot represents alpha $_{2 \mathrm{U}}-\mathrm{globulin}$, an

Table IV. mRNA Activity Profiles in Azotemia

\begin{tabular}{lccc}
\hline \multirow{4}{*}{ Spot intensity (cpm/spot) } \\
\cline { 2 - 4 } Spot no. & Control (10) & Pair fed (9) & Azotemic (8) \\
\hline 3 & $557 \pm 136^{*}$ & $219 \pm 159 \ddagger$ & $169 \pm 46 \ddagger$ \\
4 & $683 \pm 138$ & $785 \pm 138$ & $270 \pm 67 \ddagger$ \\
8 & $1,116 \pm 150$ & $536 \pm 69 \ddagger$ & $372 \pm 97 \ddagger$ \\
10 & $1,587 \pm 144$ & $435 \pm 73 \ddagger$ & $110 \pm 57 \ddagger \S$ \\
15 & $2,945 \pm 374$ & $1,342 \pm 411 \ddagger$ & $96 \pm 59 \ddagger \S$ \\
20 & $3,858 \pm 720$ & $1,367 \pm 152 \ddagger$ & $1,947 \pm 99 \dagger$ \\
21 & $375 \pm 79$ & $172 \pm 26 \ddagger$ & $25 \pm 12 \ddagger \S$
\end{tabular}

* Mean \pm SEM. Data represent videodensitometric intensities of all autoradiographic spots found to be altered in either azotemic or pairfed rats. Spots are numbered as in Fig. 2. Numbers in parentheses indicate number of animals studied. ‡ Different from control, $P<0.05$. $\S$ Different from pair fed, $P<0.05$. 
Table V. Analysis of Covariance between Spot Intensities, Thyroidal Status, and Food Intake

\begin{tabular}{|c|c|c|c|c|c|}
\hline \multirow[b]{2}{*}{ Spot } & \multicolumn{5}{|c|}{ Covariates } \\
\hline & $\mathrm{NT}_{3}$ & $\mathrm{FT}_{3}$ & Food & $\mathrm{NT}_{3}$ and Food & $\mathrm{FT}_{3}$ and Food \\
\hline 3 & $0.12^{*}$ & $0.10^{*}$ & NR & $0.79^{*}$ & $0.17^{*}$ \\
\hline 4 & NR & 0.02 & NR & NR & NR \\
\hline 8 & 0.0009 & 0.01 & $0.22^{*}$ & $0.44^{*}$ & $0.10^{*}$ \\
\hline 10 & 0.004 & NR & 0.009 & $0.11^{*}$ & 0.02 \\
\hline 15 & 0.09 & 0.0007 & 0.002 & 0.05 & 0.01 \\
\hline 20 & NR & NR & NR & NR & NR \\
\hline 21 & NR & NR & 0.01 & NR & NR \\
\hline
\end{tabular}

The probability of obtaining the observed differences among the adjusted group mean spot intensities by chance alone is presented for each covariant. Asterisks indicate that no significant differences persist after adjustment of group means, a finding compatible with a causal relationship between the spot intensity and the covariates. Absence of asterisks indicates persistence of significant differences between means, a finding not suggestive of causal relationships. NR indicates a lack of correlation between spot intensity and the covariate. Spot intensities were subjected to $\log$ transformation $\left[\log _{\mathrm{n}}\right.$ (spot intensity +1$)]$. $N$, nuclear. $F$, free.

exportable hepatic protein found in male rats, which is excreted in the urine and is dependent on testosterone, growth hormone, and cortisol for its synthesis (23). One of the mRNA sequences (spot 4) fell only in azotemic animals whereas the remaining six were reduced in pair-fed animals as well. Despite the striking overlap in the sequences affected, the reduction in food intake could not account for all of the changes observed. Thus, three of the sequences were reduced to a significantly greater extent in azotemic rats than in the pair-fed group. Moreover, analysis of covariance established that only for one spot, spot 8 , could the differences between groups be accounted for by food intake alone.

The possibility that the genomic alterations were due to a lowering of circulating $T_{3}$ was explored in view of previous reports by Lim et al. suggesting that subtotal nephrectomy results not only in a lower circulating $\mathrm{T}_{3}$ but also in diminished activity of hepatic $\alpha$-GPD and ME (5). These authors, therefore, proposed that the nephrectomized animal was a potentially useful model of the clinical "low $\mathrm{T}_{3}$ syndrome" that characterizes many chronic illnesses in man (24).

Our results do not, however, support the concept that a reduction in thyroid hormone function at the tissue level accounts for the changes observed in mRNA activity profiles, except perhaps for spot 3 . Most important was the finding that despite a $32 \%$ reduction in the total $T_{3}$ level the mean concentration of free $T_{3}$ in the azotemic rats did not differ significantly from that in normal animals, owing largely to a decrease in the plasma binding of $T_{3}$. Moreover, there was no significant reduction in the level of nuclear $T_{3}$.

Although the difference in the mean free $T_{3}$ concentration between azotemic and normal animals was not statistically significant, $20 \%$ of azotemic rats did exhibit a subnormal free $\mathrm{T}_{3}$ concentration. Therefore, we investigated the potential relationship of free $T_{3}$ and nuclear $T_{3}$ with the intensity of specific mRNA translational products by an analysis of covariance. This analysis showed that only one sequence (spot 3) revealed a significant relationship between spot intensity and the level of free $T_{3}$ or nuclear $T_{3}$ alone.

Group-related differences were more effectively excluded by the use of nuclear $T_{3}$ and food intake as combined covariates for spots 3,8 , and 10 . However, it appears highly unlikely that thyroid hormone alone acts as a major determinant of the observed changes in azotemia, especially in view of our finding of nonsignificant differences between the levels of hepatic $\alpha$-GPD and ME, two exceedingly $\mathrm{T}_{3}$-sensitive enzymes.

Our studies also cast considerable doubt on the general suitability of the azotemic animal as a model of low $T_{3}$ syndrome in man. Thus, in man there is a clear decrease in the concentration of $T_{3}$, which is not primarily determined by a decrease in plasma protein binding (6). In addition, the net production rate of $T_{3}$ in azotemic man is decreased whereas in our model it remains unchanged. Since in other studies we have shown that in the normal rat the bulk of circulating $T_{3}$ is derived from the peripheral conversion of $T_{4}$ (Kinlaw, W. B., H. L. Schwartz, and J. H. Oppenheimer, unpublished observations) it appears highly unlikely that the 3-wk azotemic animal exhibits any evidence of diminished peripheral $T_{4}$ to $\mathrm{T}_{3}$ conversion, a hallmark of the clinical syndrome.

The discrepancy between our findings and those of Lim et al. (5) may be related to the fact that these investigators made most of their observations 6 wk after nephrectomy, rather than after the 3-wk period we used. Contrary to our results, Lim et al. reported diminished levels of hepatic $\alpha$-GPD activity and a lowered free $T_{3}$ index as determined by resin assay. Thus, it appears possible that a prolonged period of experimental azotemia may produce tissue hypothyroidism. Nevertheless, these authors did show a decrease in $\alpha$-GPD at 4 wk, when the total $T_{3}$ was still not different from normal.

The results of the present set of experiments should also be compared with previously published reports from our group dealing with the genomic effect of $5 \mathrm{~d}$ of complete starvation and the effect of total thyroidectomy (2). In those states, more affected mRNA sequences were reported than in the present studies with azotemic and pair-fed animals. The activity of eight mRNA's fell in hypothyroidism whereas seven showed an increase. In starvation, nine mRNA sequences decreased and six increased. Remarkably, however, almost all of the mRNA sequences that decreased in azotemia were also reduced in 5-d starvation and hypothyroidism. The larger number of changing mRNA sequences after 5-d starvation suggests that this stimulus is more potent than those represented either by 
3 wk of pair-feeding or by azotemia. This conclusion appears reasonable because normal rats cannot survive for more than 6 to $7 \mathrm{~d}$ of total starvation. The animal starved for $5 \mathrm{~d}$ can therefore be considered to be preterminal.

Although our data indicate that the genomic effects of azotemia cannot be attributed exclusively to diminished food intake, the finding that six of the seven sequences reduced by azotemia are also reduced by pair feeding animals is intriguing. A possible explanation is that azotemia is characterized by a reduction in nutrient use. This could result in mRNA activity changes similar to those observed after simple food deprivation. Perhaps such a reduction in nutrient use could be mediated in part by the well-documented resistance to both insulin (25) and growth hormone (26) in the azotemic state. The observation of profoundly lowered levels of a newly described growth hormone-dependent plasma protein of hepatic origin in sera of our azotemic rats by Berry and Seelig (personal communication) provides additional evidence of an impaired hepatic response to growth hormone in this model.

It appears possible that the mRNA activity profile of the azotemic animal may be characteristic of other examples of systemic catabolic disease. The adaptive value of the decrease in specific mRNA sequences observed, however, remains speculative. We have previously proposed that starvation is associated with a selective decrease in the level of specific mRNA's coding for proteins which do not play an essential role in lifepreserving processes (2). This could result in fuel and energy conservation. A similar explanation could be advanced for the changes in azotemia and catabolic disease in general. The finding that the mRNA for alpha ${ }_{2 \mathrm{U}}$-globulin (spot 15) decreases to $3 \%$ of its control value in azotemia would be in accord with this hypothesis. Alpha ${ }_{2 u}$-globulin is present only in male rats and is presumed to subserve a reproductive function in this sex. This might qualify the protein as optional under the circumstances. In this context, cessation of growth could also be considered an adaptive phenomenon. Both the failure of the animal to grow and the fall in alpha ${ }_{24}$-globulin, which is highly sensitive to growth hormone (23) could be due to the development of growth hormone resistance in the azotemic rat.

\section{Acknowledgments}

We thank Dr. Thomas Hostetter for his valuable advice and critique. We also gratefully acknowledge the expert technical assistance of M. E. Domeier, R. Gunville, A. Martinez-Tapp, and N. Zilz, as well as the aid of H. Pharis, L. Spangler, and B. Dodge in preparing the manuscript.

This work was supported by the following grants from the National Institutes of Health: grant AM19812 and National Research Service Training Grant AM07203 (to Dr. Oppenheimer); Research Service Award AM07110 (to Dr. Kinlaw); National Research Service Award AM06607 (to Dr. Carr); and Clinical Investigator Award I-K08AM00800 (to Dr. Mariash).

\section{References}

1. Seelig, S., C. Liaw, H. C. Towle, and J. H. Oppenheimer. 1981. Thyroid hormone augments and attenuates hepatic gene expression at a pretranslational level. Proc. Natl. Acad. Sci. USA. 78:4733-4737.

2. Carr, F. E., S. Seelig, C. N. Mariash, H. L. Schwartz, and J. H. Oppenheimer. 1983. Starvation and hypothyroidism exert an overlapping influence on rat hepatic messenger RNA activity profiles. J. Clin. Invest. 72:154-163.

3. Carr, F. E., C. Bingham, J. H. Oppenheimer, C. Kistner, and C. N. Mariash. 1984. Quantitative investigation of hepatic genomic response to hormonal and pathophysiological stimull by multivariate analysis of two-dimensional mRNA activity profiles. Proc. Natl. Acad. Sci. USA. 81:974-978.

4. Chantler, C., E. Lieberman, and M. A. Holliday. 1974. A rat model for the study of growth failure in uremia. Pediatr. Res. 8:109113.

5. Lim, V. S., C. Henriquez, H. Seo, S. Refetoff, and E. Martino. 1980. Thyroid function in a uremic rat model. J. Clin. Invest. 66:946954.

6. Lim, V., V. Fang, A. Katz, and S. Refetoff. 1977. Thyroid dysfunction in chronic renal failure. A study of the pituitary-thyroid axis and peripheral turnover kinetics of thyroxine and triiodothyronine. J. Clin. Invest. 60:522-534.

7. Chanutin, A., and E. B. Ferris. 1932. Experimental renal insufficiency produced by partial nephrectomy. Arch. Int. Med. 49:767787.

8. Liaw, C., S. Seelig, C. N. Mariash, J. H. Oppenheimer, and H. C. Towle. 1983. Interactions of thyroid hormone, growth hormone, and high carbohydrate, fat-free diet in regulating several rat liver messenger ribonucleic acid species. Biochemistry. 22:213-221.

9. O'Farrell, P. H. 1975. High resolution two-dimensional electrophoresis of proteins. J. Biol. Chem. 10:4007-4021.

10. Mariash, C. N., S. Seelig, and J. H. Oppenheimer. 1981, A rapid, inexpensive quantitative technique for the analysis of twodimensional electrophoretograms. Anal. Biochem. 121:388-394.

11. Hsu, R., and H. Lardy. 1969. Malic enzyme. Methods Enzymol. 13:230-235.

12. Lee, $Y$., and H. Lardy. 1965. Influence of thyroid hormones on L-alpha-glycerophosphate dehydrogenases and other dehydrogenases in various organs of the rat. J. Biol. Chem. 240:1427-1436.

13. Lowry, O., N. Rosebrough, A. Farr, and R. Randall. 1951. Protein measurement with the Folin phenol reagent. J. Biol. Chem. 193:265-275.

14. Giles, K., and A. Meyers. 1965. An improved diphenylamine method for the estimation of deoxyribonucleic acid. Nature (Lond.). 206:93.

15. Fleck, A., and H. N. Munro. 1962. The precision of ultraviolet absorption measurements in the Schmidt-Tannhauser procedure for nucleic acid estimation. Biochim. Biophys. Acta. 55:571-583.

16. Surks, M. I., A. R. Schadlow, and J. H. Oppenheimer. 1972. A new radioimmunoassay for L-triiodothyronine. Measurements in thyroid disease and in patients maintained on hormonal replacement. J. Clin. Invest. 51:3104-3113.

17. Oppenheimer, J. H., R. Squef, M. I. Surks, and H. Hauer. 1963. Binding of thyroxine by serum proteins evaluated by equilibrium 
dialysis and electrophoretic techniques. Alterations in nonthyroidal illness. J. Clin. Invest. 42:1769-1782.

18. Oppenheimer, J. H., and E. Gurpide. 1979. Quantitation of production, distribution, and interconversion of hormones. In Endocrinology. Vol. III. L. J. De Groot, G. F. Cahill, W. D. Odell, L. Martini, J. T. Potts, D. H. Nelson, E. Steinberger, and A. I. Winegrad, editors. Grune \& Stratton Inc., New York. 2029-2036.

19. Oppenheimer, J. H., H. L. Schwartz, and M. I. Surks. 1975. Determination of common parameters of iodothyronine metabolism and distribution in man by noncompartmental analysis. J. Clin. Endocrinol. Metab. 41:319-324.

20. Oppenheimer, J. H., H. L. Schwartz, and M. I. Surks. 1974. Tissue differences in the concentration of triiodothyronine binding sites in the rat: liver, kidney, pituitary, heart, brain, spleen, and testis. Endocrinology. 95:897-903.

21. Snedecor, G. W., and W. G. Cochran. 1980. Statistical Methods. Iowa State University Press, Ames, lowa. 54, 217, 365.

22. Towle, H. C., W. H. Dillmann, and J. H. Oppenheimer. 1979.
Messenger RNA content and complexity of euthyroid and hypothyroid rat liver. J. Biol. Chem. 254:2250-2257.

23. Roy, A. K. 1983. Role of thyroid hormone in the expression of $\alpha_{2 \mathrm{v}}$-globulin and other multihormonally regulated genes. In Molecular Basis of Thyroid Hormone Action. J. H. Oppenheimer and H. H. Samuels, editors. Academic Press, New York. 224.

24. Bermudez, R., M. I. Surks, and J. H. Oppenheimer. 1975. High incidence of decreased serum triiodothyronine concentrations in patients with nonthyroidal disease. J. Clin. Endocrinol. Metab. 41:27-40.

25. Kauffman, J. M., and J. F. Caro. 1983. Insulin resistance in uremia. Characterization of insulin action, binding, and processing in isolated hepatocytes from chronic uremic rats. J. Clin. Invest. 71:698708.

26. Schalch, D. S., P. J. Burstein, S. J. Tewel, B. Draznin, and C. A. Eules. 1981. The effect of renal impairment on growth in the rat. Relationship to malnutrition and serum somatomedin levels. Endocrinology. 108:1683-1688. 